\title{
Biochemical features of alcohol-induced liver disease in native versus non-native Canadians
}

GY MINUK, MD, FRCPC, W THOMPSON

ABSTRACT: The medical records of 37 native and 40 non-native adult Canadians with alcohol-induced liver disease were reviewed in order to determine whether a biochemical pattern of bile ductular injury (increase in serum alkaline phosphatase levels) was more common and/or severe in native versus non-native Canadians. The results of this retrospective review revealed that serum alkaline phosphatase levels were markedly elevated (at least three times the upper limit of normal) in six of $37(16 \%)$ native Canadians as compared to three of $40(7.5 \%)$ non-native Canadians $(\mathrm{P}<0.05)$. Moreover, the mean peak serum alkaline phosphatase level for native Canadians was significantly higher than for non-natives $(262 \pm 188 \mathrm{iu} / \mathrm{L}$ versus $197 \pm 101 \mathrm{iu} / \mathrm{L}$, respectively, mean \pm SD, $P<0.05)$. Other liver enzyme and function tests were similar in the two groups. The study also revealed that the mean duration of hospital stay for native Canadians with alcoholic hepatitis is significantly shorter than for nonnatives ( $8.5 \pm 6.0$ versus $12.7 \pm 11.2$ days, respectively, $\mathrm{P}<0.05)$ and the overall duration of hospital stay for patients with alcoholic liver injury has decreased in recent years from 26 days (May 1984-85) to 9.3 days (May 1987-88). The results of this study indicate that alcoholic liver disease in native Canadians is associated with higher serum alkaline phosphatase levels than in non-native Canadians. Can J Gastroenterol 1990;4(4):163-166 (pour résumé, voir page 164)

Key Words: Alcoholic hepatitis, Alkaline phosphatase, Cholestasis, Liver disease

Department of Medicine, University of Manitoba, Health Sciences Clinical Research Centre, Winnipeg, Manitoba

Correspondence and reprints: Dr GY Minuk, Liver Disease Unit, Health Sciences Centre,

820 Sherbrook Street, Winnipeg, Manitoba R3A IR9

Received for publication August 1, 1989. Accepted January 22, 1990
E LEVATED SERUM ALKALINE PHOSphatase levels are reported to occur in approximately 60 to $80 \%$ of patients with alcoholic hepatitis (1). In the majority of cases the extent of the abnormality is mild and unlikely to result in further investigations. More marked abnormalities (defined as serum alkaline phosphatase levels greater than threefold the upper limit of normal) occurs in approximately $5 \%$ of patients with alcoholic liver disease and frequently results in the need for further investigations to exclude mechanical obstruction of the biliary tract (2-5). These investigations are associated with increased patient morbidity and result in a more costly, prolonged hospital stay. Recently, it had been noted that the incidence of markedly elevated serum alkaline phosphatase levels appeared to be greater in adult native Canadian patients with alcoholic hepatitis than non-natives admitted to hospital with the same 


\section{Etude comparative des caractéristiques biochimiques des maladies hépatiques dues à alcool chez les Canadiens autochtones et non-autochtones}

RESUME: Les dossiers médicaux d'adultes Canadiens atteints de maladies hépatiques dues à l'alcool, 37 autochtones et 40 non-autochtones, ont été examinés afin de déterminer si un profil biochimique des lésions du cholédoque (élévation des taux sériques de phosphatase alcaline) était plus fréquent ou sévère chez les autochtones que chez les non-autochtones. Les résultats de cette étude rétrospective indiquent que les taux sériques de phosphatase alcaline étaient beaucoup plus élevés (d'au moins trois fois plus que la limite supérieure normale) chez six de $37(16 \%)$ autochtones, comparés à trois de $40(7,5 \%)$ autres Canadiens $(\mathrm{P}<0.05)$. De plus, dans le cas des autochtones, le pic moyen du taux des phosphatases alcalines sériques était significativement plus élevé que chez les non-autochtones ( $262 \pm 188 \mathrm{ui} / \mathrm{L}$ contre $197 \pm 101 \mathrm{ui} / \mathrm{L}$, respectivement, moyenne $\pm \mathrm{DS}, \mathrm{P}<0,05)$. Les autres épreuves fonctionnelles hépatiques et tests de la fonction enzymatique étaient similaires dans les deux groupes. L'étude montre également que, chez les Canadiens autochtones souffrant d'hépatite alcoolique, la durée moyenne de l'hospitalisation est significativement plus courte que chez les non-autochtones $(8,5 \pm 6,0$ contre $12,7 \pm 11,2$ jours, respectivement, $P<0,05)$, et que la durée globale du séjour à l'hôpital chez les patients souffrant de lésions hépatiques dues à l'alcool est passée de 26 jours (mai 1984-85) à 9,3 jours (mai 1987-88) au cours des dernières années. Les résultats de cette étude révèlent que, dans le cas des maladies hépatiques dues à l'alcool, les autochtones présentent des taux de phosphatases alcalines sériques plus élevés que les non-autochtones.

diagnosis. In order to test the accuracy of this observation, the medical records and laboratory findings of native Canadians with alcohol-induced liver injury were reviewed and the results compared with those from adult nonnative patients admitted to hospital during the same time period with the same diagnosis.

\section{PATIENTS AND METHODS}

The medical records of all patients admitted to Winnipeg's Health Sciences Centre General Hospital during the period May 1984 to May 1988 with a diagnosis of acute alcoholic hepatitis were reviewed. Native Canadians were identified by the presence of a treaty number on their admission data sheet. The study was designed to include 100 charts consisting of the first 25 each of native Canadian males, native Canadian females, non-native males and non-native females fulfilling the following criteria: a history of excessive and prolonged alcohol intake (more than $100 \mathrm{~g} /$ day for more than five years); an admission and discharge diagnosis of acute alcoholic hepatitis with documentation on admission of right upper quadrant tenderness, leukocytosis and/or fever; no radiologic or bacteriologic evidence of biliary stones or sepsis; absence of surgical procedures during the hospital stay; and absence of viral, immunologic or metabolic evidence for acute or chronic liver disease

Throughout the four-year period, 162 cases had been admitted and discharged from hospital with a diagnosis of acute alcoholic hepatitis (Table 1). Of these, 25 native Canadian males, 25 native Canadian females, 25 nonnative males and 23 non-native females were identified who fulfilled the above criteria. Prior to analysis the records were also screened for evidence of pancreatitis. Eleven records (six na-

\begin{tabular}{|c|c|c|c|}
\hline & \multicolumn{2}{|c|}{ Alkaline phosphatase } & \multirow[t]{2}{*}{ Significance } \\
\hline & Increased* & Not increased ${ }^{\dagger}$ & \\
\hline Aspartate aminotransferase (iu/L) & $334 \pm 229$ & $239 \pm 198$ & $P \leq 0.05$ \\
\hline Bilirubin $(\mu \mathrm{mol} / \mathrm{L})$ & $188 \pm 149$ & $105 \pm 151$ & $P=0.07$ \\
\hline Prothrombin time (s) & $16.6 \pm 2.7$ & $14.6 \pm 2.6$ & $P<0.05$ \\
\hline Abumin $(\mathrm{g} / \mathrm{L})$ & $19.1 \pm 8.8$ & $33.4 \pm 9.1$ & $P<0.0001$ \\
\hline
\end{tabular}

TABLE 1

Details of recruitment

\begin{tabular}{lccc}
\hline $\begin{array}{l}\text { Year of } \\
\text { admission }\end{array}$ & Cases & $\begin{array}{c}\text { Hospital } \\
\text { stay } \\
\text { (days) }\end{array}$ & Range \\
\hline $1984-85$ & 43 & 26.0 & 2 to 120 \\
$1985-86$ & 45 & 15.3 & 1 to 184 \\
$1986-87$ & 30 & 14.2 & 1 to 110 \\
$1987-88$ & 44 & 9.3 & 1 to 30 \\
\hline
\end{tabular}

tive, five non-native) were discarded due to elevated serum amylase results (greater than twice the upper limit of normal). A further 10 records (seven native, three non-native) were discarded due to the absence of serum amylase results in the chart. Thus, 77 cases ( 37 natives and 40 non-natives) constituted the study population for this review.

Statistics: A Student's $t$ test for unpaired data and Fisher's exact test were performed where appropriate. The results are given as the mean \pm standard deviation.

\section{RESULTS}

Demographic details: Of the 37 native Canadians, 18 were male and 19 female. Their mean age was $44.6 \pm 14.3$ years (range 24 to 80 ). Of the 40 non-natives, 19 were male, 21 female, with a mean age of $48.1 \pm 14.6$ years (range 24 to 84 ). The mean duration of hospital stay was $8.5 \pm 6.0$ days for the native patients and $12.7 \pm 11.2$ days for non-natives $(\mathrm{P}<0.05)$.

Liver biochemistry results: Six of 37 $(16 \%)$ native Canadians had serum alkaline phosphatase levels greater than three times the upper limit of normal as compared to three of $40(7.5 \%)$ non-natives $(\mathrm{P}<0.05)$. Serum alkaline phosphatase levels four times the upper 
limit of normal were documented in three $(8 \%)$ of the native Canadians but none of the non-natives. Aspartate aminotransferase, bilirubin levels and prothrombin times tended to be higher and albumin levels lower in patients with marked elevations in serum alkaline phosphatase levels when compared with those with normal or only mildly elevated alkaline phosphatase levels (Table 2).

Table 3 provides the results of certain liver enzyme tests (alkaline phosphatase, gammaglutamyltransferase and aspartate aminotransferase), and liver function tests (serum bilirubin, albumin and prothrombin time) for native and non-native populations. The hospital day at which the laboratory abnormality was most pronounced is also provided. The only significant difference between the two groups was with respect to serum alkaline phosphatase levels. In native Canadians, the mean peak serum alkaline phosphatase level was $262 \pm 188 \mathrm{iu} / \mathrm{L}$ compared to $197 \pm 99 \mathrm{iu} / \mathrm{L}$ in the non-native population $(\mathrm{P}<0.05)$. The time to peak serum alkaline phosphatase levels was also different between the two groups (1.9 \pm 1.9 versus $4.2 \pm 6.8$ days, respectively, $\mathrm{P}<0.05$ ). Serum gammaglutamyltransferase levels were elevated in all patients with elevated serum alkaline phosphatases suggesting that at least a portion of the alkaline phosphatase was of hepatobiliary origin.

Ultrasound and histologic findings: Twenty-two of 67 patients with elevated serum alkaline phosphatase levels underwent ultrasound examinations of the liver ( 15 natives and seven non-natives). In 11 (50\%) of these cases, features consistent with fatty infiltration (increased echogenicity and decreased vascularity) were noted. Aside from one simple cyst, no space-occupying lesions were seen.

Nine liver biopsies were performed. Five of the biopsies were derived from patients with elevated serum alkaline phosphatase levels. Two of these five individuals had markedly elevated alkaline phosphatase levels. Four of the five were native Canadians; one was non-native. Mallory bodies and

TABLE 3

Biochemical features of alcoholic hepatitis in native and non-native Canadians

\begin{tabular}{|c|c|c|c|}
\hline & $\begin{array}{l}\text { Native Canadians } \\
\qquad(n=37)\end{array}$ & $\begin{array}{c}\text { Non-native } \\
\text { Canadians }(n=40)\end{array}$ & Significance \\
\hline $\begin{array}{l}\text { Alkaline phosphatase } \\
\text { (normal } 30-125 \mathrm{iu} / \mathrm{L} \text { ) }\end{array}$ & $\begin{array}{l}262 \pm 188(54-1150) \\
1.9 \text { days }(n=37)\end{array}$ & $\begin{array}{l}197 \pm 99(70-412) \\
4.1 \text { days }(n=40)\end{array}$ & $\begin{array}{l}P<0.05 \\
P<0.05\end{array}$ \\
\hline $\begin{array}{l}\text { y glutamyl transferase } \\
\text { (normal } 5-55 \mathrm{iu} / \mathrm{L} \text { ) }\end{array}$ & $\begin{array}{l}857 \pm 740(78-2880) \\
2.4 \text { days }(n=23)\end{array}$ & $\begin{array}{c}1151 \pm 731(55-2550) \\
2.6 \text { days }(n=27)\end{array}$ & NS \\
\hline $\begin{array}{l}\text { Aspartate aminotransferase } \\
\text { (normal }<50 \mathrm{iu} / \mathrm{L})\end{array}$ & $\begin{array}{l}249 \pm 184(54-850) \\
2.5 \text { days }(n=37)\end{array}$ & $\begin{array}{c}257 \pm 221(32-1367) \\
3.6 \text { days }(n=40)\end{array}$ & NS \\
\hline $\begin{array}{l}\text { Total bilirubin } \\
\text { (normal } 3-18 \mu \mathrm{mol} / \mathrm{L} \text { ) }\end{array}$ & $\begin{array}{l}106 \pm 143(3-520) \\
2.7 \text { days }(n=36)\end{array}$ & $\begin{array}{l}122+161(3-761) \\
4.2 \text { days }(n=39)\end{array}$ & NS \\
\hline $\begin{array}{l}\text { Albumin } \\
\text { (normal } 60-80 \mathrm{~g} / \mathrm{L} \text { ) }\end{array}$ & $\begin{array}{l}31.7 \pm 10.7(6-46) \\
3.4 \text { days }(n=37)\end{array}$ & $\begin{array}{l}31.7 \pm 91,7(4.45) \\
3.9 \text { days }(n=39)\end{array}$ & NS \\
\hline $\begin{array}{l}\text { Prothrombin time } \\
\text { (normal } 11.3-13.7 \mathrm{~s} \text { ) }\end{array}$ & $\begin{array}{l}15.1 \pm 3.1(11-23) \\
3.1 \text { days }(n=37)\end{array}$ & $\begin{array}{l}14.6 \pm 2.7(11.5-23) \\
4.1 \text { days }(n=40)\end{array}$ & NS \\
\hline
\end{tabular}

Values given are mean \pm standard deviation (range), days to peak abnormality ( $n=$ number of patients). NS Not significant

polymorphonuclear infiltrates were present in five of the biopsies. Macrovesicular fatty infiltration of hepatocytes was noted in four cases and extensive fibrosis in three. Bile stasis was present in only one case (a native Canadian with markedly elevated serum alkaline phosphatase levels). There was no evidence of portal edema, cholangitis or ductular proliferation in any of the biopsies.

\section{DISCUSSION}

The results of this retrospective review provided interesting findings with respect to alcoholic liver disease in this patient population. Specifically, marked increases in serum alkaline phosphatase levels occurred twice as often in native than in non-native Canadians. Moreover, the mean peak serum alkaline phosphatase level was significantly higher in native Canadian patients with alcohol-induced liver injury. In addition, the study revealed that the duration of hospital stay for patients with alcohol-induced liver injury is significantly shorter for native Canadians (discharged after a mean of 8.5 days) than for non-native Canadians (discharged after a mean of 12.7 days). Finally, the duration of hospital stay for all alcoholics with liver injury appears to have progressively decreased in recent years.

The reason for higher serum alkaline phosphatase levels in native Canadians who drink excessive amounts of alcohol is unclear. That serum aminotransferase, bilirubin and prothrombin levels were higher and albumin levels lower in patients with marked alkaline phosphatase abnormalities suggests that the extent of hepatic injury may be an important factor. It is conceivable therefore that native Canadian alcoholics consume larger amounts of alcohol or their pattern of consumption is such that hepatic injury is more extensive than in non-natives. Unfortunately, accounts of the amount of alcohol ingested or the pattern of ingestion were considered too inaccurate to pursue this possibility further. Alternatively, a genetic predisposition to the toxic effects of alcohol on the liver or to its manifestation as bile ductular injury may exist in native Canadians (6). Although the shorter duration of hospitalization to peak serum alkaline phosphatase levels tends to support this hypothesis, the possibility that native Canadians might present to the hospital at a later stage of their disease could also explain this finding.

The small number of liver biopsies performed precluded an attempt to determine whether other possible cholestatic factors that can be associated with elevated serum alkaline phosphatase levels, such as the extent of fatty infiltration, differed in the two populations (7). The exclusion of 
patients with gallstones, bacterial sepsis or pancreatitis argues against the likelihood of these being important contributing factors $(3-5)$.

The reason for the shorter hospital stay among native Canadians is likely multifactorial. As discussed earlier, native Canadians may present at a later stage of their illness and thus require fewer in-hospital days. They may also recover from their illness more promptly. More frequent self-initiated discharges is another possibility. Finally, there may be significant differences between native and non-native alcoholics with respect to access to places of residence within the community that would affect the timing of discharge.

ACKNOWLEDGEMENTS: The authors acknowledge the support of the Manitoba Medical Services Foundation and the assistance of the staff at the Health Sciences Centre, Medical Records Department. The authors also thank Ms D Byron for her prompt and accurate typing of the manuscript.

\section{REFERENCES}

1. Galambos JT. Alcoholic hepatitis. In: The Liver and its Diseases, 1st edn. New York: Intercontinental Medical Book Corp, 1974:255-67.
A somewhat unexpected finding was the progressive decrease in the average duration of hospital stay for all cases of alcohol-induced liver injury within the past four years from 26 days (May 1984-85) to 9.3 days (May 1987. 88 ). This $64 \%$ decline in hospital stay duration is unlikely to reflect improvements in either diagnostic or therapeutic modalities, as investigations and treatment for alcoholic liver injury have remained essentially unchanged over the past decade. A more likely explanation is an increasing awareness of healthcare costs and an increasing demand for acute care beds. Of interest is the finding that peak serum enzyme abnormalities occurred within the first

2. Perrillo RP, Griffin R, DeSchryverKecskemeti I, Lander JL, Zuckerman GR. Alcoholic liver disease presenting with marked elevation of serum alkaline phosphatase: A combined clinical and pathological study. Dig Dis 1978;23:1061-6.

3. Snape WJ Jr, Long WB, Trotman BW, et al. Marked alkaline phosphatase elevation with partial common bile duct obstruction due to calcific pancreatitis. Gastroenterology 1976;70:70-3.

4. Warshaw AL, Schapiro RH, Ferrucci JT, et al. Persistent obstructive jaundice, cholangitis, and biliary cir- five days of hospital stay, suggesting that even earlier discharges are conceivable for the majority of patients with alcoholic hepatitis.

In conclusion, the results of this study suggest that native Canadians with alcohol-induced liver injury may have a different biochemical profile than non-natives and that a marked increase in the serum alkaline phosphatase level is not an uncommon manifestation of alcohol-induced liver injury in native Canadians. Increased awareness of these findings could conceivably lead to fewer invasive, and costly procedures being performed in this patient population.

rhosis due to common bile duct stenosis in chronic pancreatitis. Gastroenterology 1976;70:562-7.

5. Sataline LR, Matre WJ. Significance of hyperphosphatasemia in alcoholics with liver disease. Am J Med 1963;35:323-42.

6. Weber AM, Tuchweber B, Yousef I, et al. Severe familial cholestasis in North American Indian children: A clinical model of microfilament dysfunction? Gastroenterology 1981;81:653-62.

7. Ballard H, Bernstein M, Farrar JT. Fatty liver presenting as obstructive jaundice. Am J Med 1961;30:196-201. 


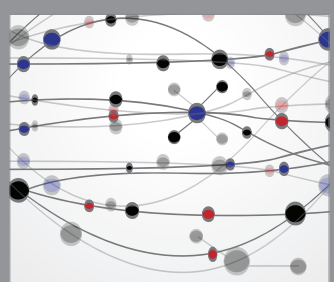

The Scientific World Journal
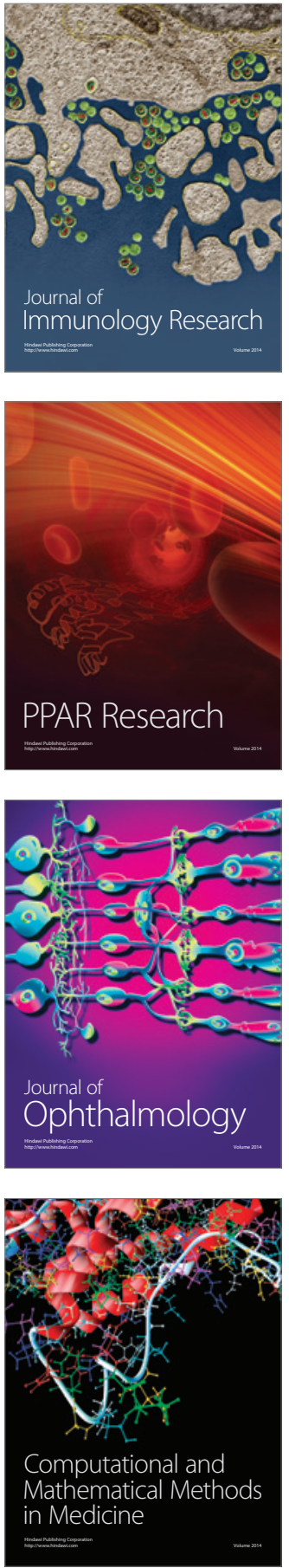

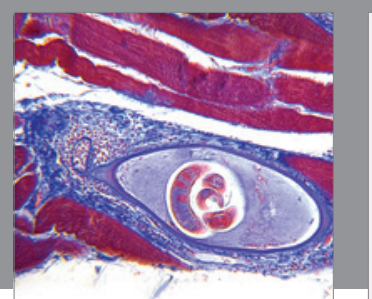

Gastroenterology Research and Practice

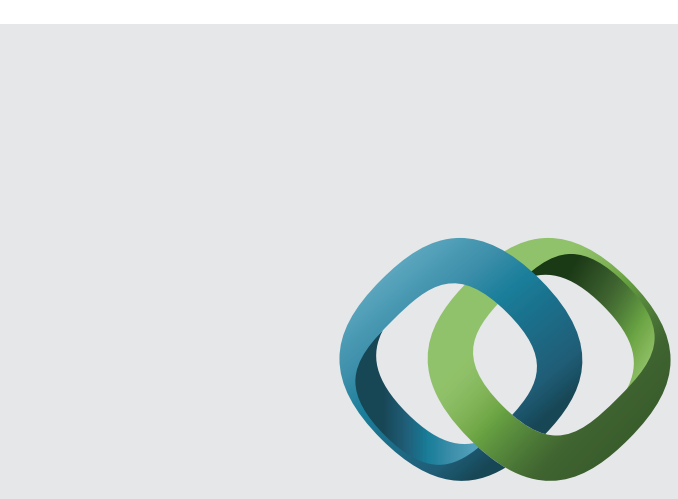

\section{Hindawi}

Submit your manuscripts at

http://www.hindawi.com
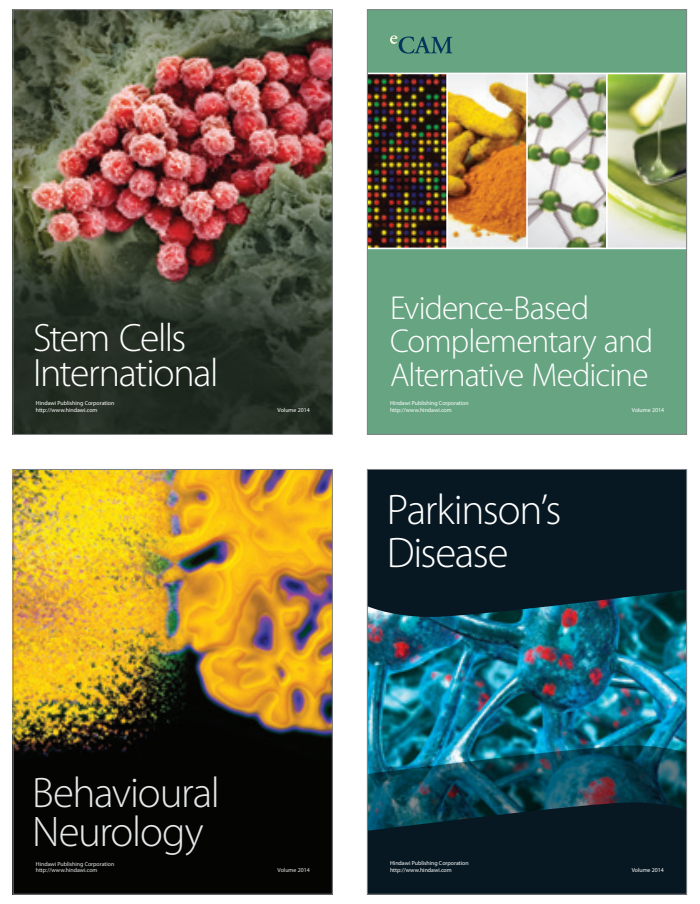
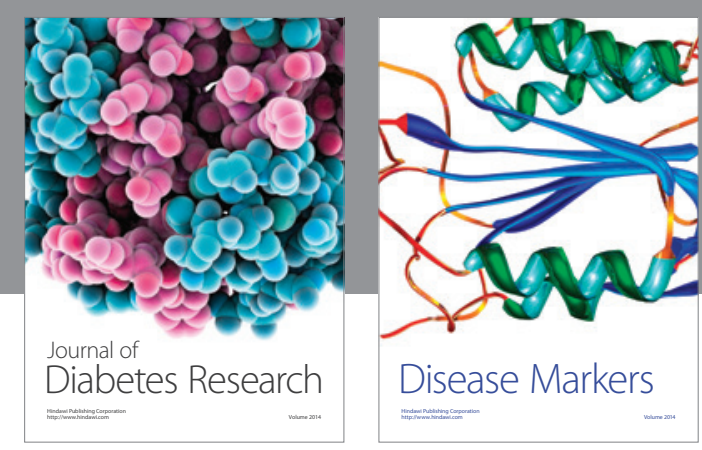

Disease Markers
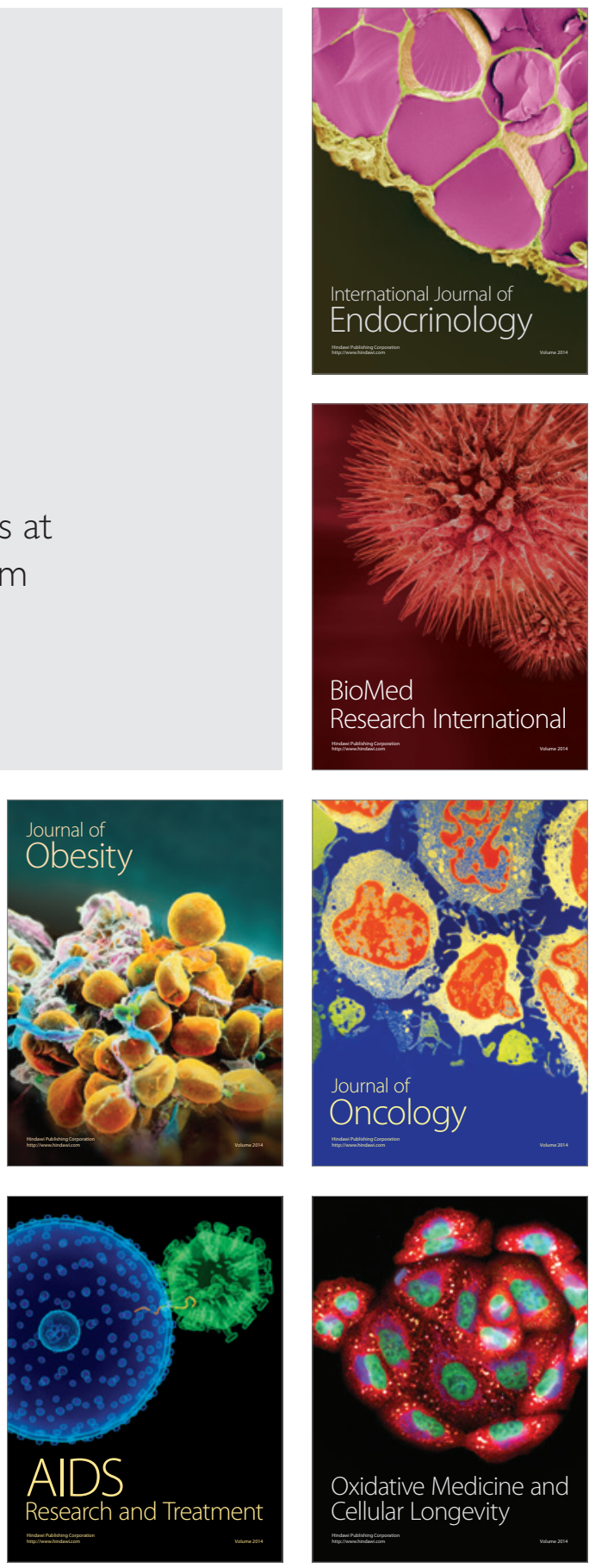